\title{
Decline in coral cover and flattening of the reefs around Mauritius (1998 - 2010)
}

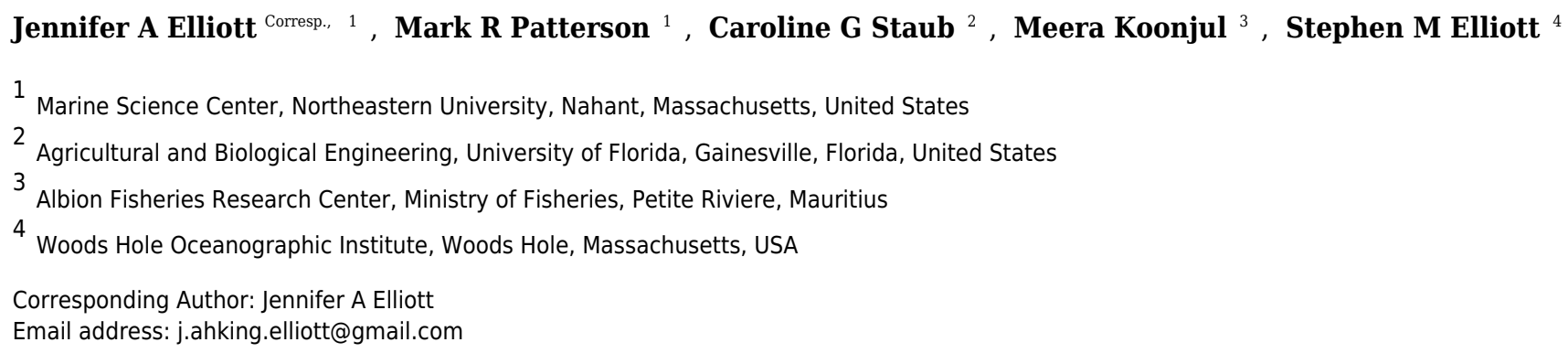

Coral reefs are degrading through the impacts of multiple anthropogenic stressors. How are coral reef communities going to change and how to protect them for future generations are important conservation questions. Using coral reef data from Mauritius, we examined changes in cover in 23 benthic groups for a 13-yr period and at 15 sites. Moreover, we determined which land-based stressor out of four (human population, agriculture, tourism, rainfall) correlated the most with the observed changes in coral reef cover. Among the stony corals, Acropora corals appeared to be the most impacted, decreasing in cover at many sites. However, the non-Acropora encrusting group increased in cover at several sites. The increase in abundance of dead corals and rubble at some sites also supported the observations of stony coral decline during the study period. Additionally, the decline in stony corals appeared to be more important in second half of the study period for all sites suggesting that a global factor rather than a local factor was responsible for this decline. There was little change in cover for the other benthic groups, some of which were quite rare. Human population was significantly correlated with changes in coral reef cover for 11 sites, followed by tourism and agriculture. Rainfall, a proxy for runoff, did not appear to affect coral reef cover. Overall, our results showed that there has been a decline of stony coral especially the ones with complex morphologies, which in turn suggest that coral reefs around Mauritius have experienced a decline in habitat complexity during the study period. Our study also suggests that humans are an important factor contributing to the demise of coral reefs around the island. 


\section{Title}

2 Decline in coral cover and flattening of the reefs around Mauritius (1998 - 2010)

3

4

5

6

\section{7}

8

11

12

13

26

27

\section{Jennifer A. Elliott (corresponding author)}

Marine Science Center

Northeastern University

430 Nahant Road

Nahant, MA 01908 USA

j.ahking.elliott@gmail.com

\section{Mark R. Patterson}

Marine Science Center

Northeastern University

430 Nahant Road

Nahant, MA 01908 USA

\section{Caroline G. Staub}

Climate Science and Climate Science Applications

Agricultural and Biological Engineering Department

University of Florida

220 Frazier-Rogers Hall

Gainesville, FL 32611 USA

\section{Meera Koonjul}

Albion Fisheries Research Centre, Ministry of Fisheries

Petite Riviere, Mauritius

\section{Stephen M. Elliott}

Woods Hole Oceanographic Institute

266 Woods Hole Road,

Woods Hole, MA 02543 USA 


\section{Abstract}

39 Coral reefs are degrading through the impacts of multiple anthropogenic stressors. How are coral

reef communities going to change and how to protect them for future generations are important conservation questions. Using coral reef data from Mauritius, we examined changes in cover in 23 benthic groups for a 13 -yr period and at 15 sites. Moreover, we determined which land-based stressor out of four (human population, agriculture, tourism, rainfall) correlated the most with the observed changes in coral reef cover. Among the stony corals, Acropora corals appeared to be the most impacted, decreasing in cover at many sites. However, the non-Acropora encrusting group increased in cover at several sites. The increase in abundance of dead corals and rubble at some sites also supported the observations of stony coral decline during the study period. Additionally, the decline in stony corals appeared to be more important in second half of the study period for all sites suggesting that a global factor rather than a local factor was responsible for this decline. There was little change in cover for the other benthic groups, some of which were quite rare. Human population was significantly correlated with changes in coral reef cover for 11 sites, followed by tourism and agriculture. Rainfall, a proxy for runoff, did not appear to affect coral reef cover. Overall, our results showed that there has been a decline of stony coral especially the ones with complex morphologies, which in turn suggest that coral reefs around Mauritius have experienced a decline in habitat complexity during the study period. Our study also suggests that humans are an important factor contributing to the demise of coral reefs around the island. 


\section{Introduction}

60 Coral reefs worldwide are declining through the impacts of many different types of natural and 61 anthropogenic stressors (Pandolfi et al., 2003). The planet's climate is changing at a pace faster 62 than ever observed before primarily due to the extensive burning of fossil fuels. As a result, the oceans are warming (IPCC, 2014) and stony corals, the foundation species of coral reefs, have

64 been observed to bleach and die on a large scale (Roberts et al., 2002; Gardner et al., 2003;

65 Pandolfi et al., 2003; Bellwood et al., 2004; Graham et al., 2006; Bruno \& Selig, 2007; Heron et 66 al., 2016; Hughes et al., 2017). Severe bleaching events are happening five times more often 67 today than in the 1980s (Hughes et al., 2018).

Over $60 \%$ of the world's coral reefs have been estimated to be threatened by local stressors arising from anthropogenic activities (Burke et al., 2012). Land clearing for agriculture and coastal urbanization have led to sediments, nutrients, and pollutants being discharged through runoff into these coastal ecosystems (Smith et al., 1981; Fabricius, 2005; Markey et al., 2007; Brodie et al., 2012). Overfishing has also caused significant changes in ecological communities and contributed to the collapses of some coastal ecosystems (Jackson et al., 2001).

How are coral reef communities going to change in the face of multiple anthropogenic stressors and what makes some species more resilient than others are critical conservation questions. Inherent biological traits (e.g. morphology, growth rate and reproductive mode) and 77 physiological mechanisms of coral species are thought to play an important role in their capabilities to respond to repeated assaults from multiple stressors (Edmunds \& Gates, 2008; Darling et al., 2012). For example, a study on coral community structure reported that coral colonies with branching morphologies bleached and died before those with massive and encrusting morphologies after a bleaching event (Loya et al., 2001). Theoretical work has also 
82 shown that at the same flow rate, an organism with a flat morphology will have a higher mass

83 transfer or diffusion rate (of gases and nutrients to and from the organism) than an organism with

84 a branched morphology (Patterson, 1992). This could in turn also lead to faster removal of

85 harmful superoxides and toxic radicals produced during stressful thermal events (Lesser, 1997),

86 providing a competitive advantage to species with a flat morphology.

87 Physical external factors can also play an important role in helping coral reef organisms face

88 multiple stressors. Localized upwelling (Glynn \& D'Croz, 1990), water-flow rates and flushing

89 of toxins have been reported to help stony corals weather thermal stresses (Nakamura \& Van

90 Woesik, 2001; 2005). Decreased light stress, e.g., in the form of shading or cloud cover or

91 turbidity can also reduce some of the impacts from stressors (Hoegh-Guldberg, 1999; Moothien

92 Pillay, Terashima \& Kawasaki, 2002; Jokiel \& Brown, 2004; Coelho et al., 2017).

93 Both global and local efforts are needed to conserve coral reefs worldwide as they continue to

94 degrade because of increasing human population and their activities (Mora, 2008; Sandin et al.,

95 2008; Smith et al., 2016; Crane et al., 2017). Long-term coral reef monitoring and studies

96 disentangling the impacts of diverse anthropogenic activities are especially important to inform

97 conservation actions. We investigated the effects of four land-based stressors on the coral reefs

98 around Mauritius. This Indian Ocean island has one of the densest human population on earth,

99 with 618 individuals $\mathrm{km}^{-2}$ in 2017 (data.worldbank.org). Moreover, a large area of the island has

100 been converted to agricultural land and the island is a prime tourist destination in the Indian

101 Ocean. The two primary goals of this study were to examine changes in coral reef cover over a

102 13-yr period, and to investigate the relationship between the land-based stressors and changes in

103 benthic communities around Mauritius. 


\section{Materials and Methods}

\section{Study sites}

106 This study was carried out at the southwestern Indian Ocean island of Mauritius ( $20^{\circ} 10^{\prime} \mathrm{S}, 57^{\circ}$

107 31' E; Fig. 1a). The island has a surface area of $1,869 \mathrm{~km}^{2}$ and possesses $240 \mathrm{~km}^{2}$ of reef habitats

108 (Turner \& Klaus, 2005). It also lies within the cyclonic belt and is visited by cyclones seasonally, 109 typically from January to March. The land area is also divided into 42 watersheds (or catchment

110 areas; Fig. 1b) (Proag, 1995). A total of 15 sites, 11 back- and four fore-reef sites, were

111 investigated. Back-reef sites (circles) were found all around the island and fore-reefs sites (stars)

112 only on the west coast, which is sheltered from the prevailing southeast trade winds (Fig. 1b).

113 The reefs around Mauritius are broken up by natural breaks that result in a series of distinct

114 lagoons. Back-reef sites were found in the lagoons that are $<3 \mathrm{~m}$ deep and $1-8 \mathrm{~km}$ wide.

115 Additionally, the island has one $10 \mathrm{~km}$ long barrier reef on the southeast coast where one of the

116 back reef site was found. This barrier reef is also next to a deep channel $(15-30 \mathrm{~m})$ that flushes

117 seawater offshore (Fig. 1b) (Turner \& Klaus, 2005). The fore-reef sites were found outside the

118 lagoons in $8-20 \mathrm{~m}$ deep waters.

119 Some 160 stony corals species have been reported in Mauritius (Moothien Pillay et al., 2002).

120 The back-reefs of Mauritius consist mainly of branching and tabular Acropora, massive Porites,

121 foliaceous Montipora and Pavona, and sand consolidated with seagrass. The narrow reef flats are

122 made up mostly of dead coral platform, stony corals and macroalgae, and the outer slopes have a

123 spur and groove system that is colonized by a diverse range of hard and soft coral genera (e.g.

124 Pocillopora, Favia, Porites, Sarcophyton and Lobophyton). For a more comprehensive

125 description of the coral reefs of Mauritius, see Turner and Klaus (2005). 


\section{Datasets}

\section{7 (a) Benthic communities}

128 Benthic coral reef monitoring data spanning over 13 years (1998 to 2010) were obtained from

129 the Albion Fisheries Research Centre (AFRC), Government of Mauritius. The data were

130 collected from three $20 \mathrm{~m}$ long transects at each site; each transect was marked by two metal

131 stakes. The line intercept method (Kaiser, 1983) was used to survey these transects. A measuring

132 tape was laid down along each transect; all benthic groups touching the tape were recorded and

133 the number of centimeters that they covered along the tape was also recorded. The number in

134 centimeters for each benthic group was then converted to percentages such that each transect

135 would be equal to $100 \%$. E.g. if sand was found from $0 \mathrm{~cm}$ to $23 \mathrm{~cm}$, then sand would be equal

136 to $(23-0) /(20 * 100) * 100=1.15 \%$ of the transect. The three transects were considered as three

137 replicates for each site.

138 The data were originally collected twice a year, once in summer (December to May) and once in

139 winter (June to November). However, later in the study period, data were sometimes only

140 collected once a year and not all sites were surveyed each year during the study period (Table S1

141 - study years by site). During this 13-yr period, the data were collected by a small group of staff

142 from the AFRC, which minimized observer error in the data.

143

144 The back-reef sites surveyed were: Albion (ALB), Anse La Raie (ALR), Baie du Tombeau

145 (BDT), Bambous Virieux (BVX), Bel Ombre (BOM), Belle Mare (BME), Île aux Bénitiers

146 (BEN), Poudre d'Or (PDO), Pte aux Sables (PTE), Trou aux Biches (TBI), Trou d'Eau Douce

147 (TDO). The four fore-reefs sites were: Albion (ALB), Île aux Bénitiers (BEN), Pte aux Sables 
148 (PTE) and Trou aux Biches (TBI). The back-reefs sites were in waters $<3 \mathrm{~m}$ deep; the fore-reefs

149 sites ALB, BEN, PTE and TBI were set up respectively at 10m, 10m, 8m and $12 \mathrm{~m}$ deep.

150 The benthic cover data were recorded as one of the following 23 groups: Acropora branching,

151 Acropora digitate, Acropora encrusting, Acropora submassive, Acropora tabulate, non-Acropora

152 branching, non-Acropora encrusting, non-Acropora foliaceous, non-Acropora submassive, non-

153 Acropora massive, fungiid coral, turf algae, macroalgae, coralline algae, Millepora spp.,

154 sponges, soft corals, zoanthids, other live, dead corals, rubble, sand and rock. Dead corals

155 consisted of calcium carbonate coral skeletons that were more or less intact that would

156 eventually become rubble when they finally break down into smaller pieces.

\section{7 (b) Land-based stressors}

158 Four land-based stressors on the coral reefs, human population, tourism, agriculture, and rainfall

159 were investigated. Spatial data for the selected stressors were gathered for the period of 1998 to

1602010 so that they would match the time period for which the benthic data were available. Data

161 for the first three stressors were obtained from the governmental organization 'Statistics

162 Mauritius' (statsmauritius.govmu.org). Rainfall data were obtained from the monthly

163 meteorological summaries (Mauritius Meteorological Services) that were made available by the

164 Mauritius Sugar Industry Research Institute (MSIRI) archives department.

165 Data for human population, agriculture and tourism were spatially reorganized using a

166 geographic information system (GIS; QGIS Lyon 2.12) such that each stressor would have one

167 value per watershed per study year (Fig. 1b). The human population data were organized as the

168 total number of people per watershed per year. The agricultural data were organized as total

169 surface area under cultivation per watershed per year. The agricultural data consisted of both

170 land under sugarcane and other food crop cultivation during the study period. For the tourism 
171 data, a tourism index was created because the available data were rather coarse; only the number

172 of hotels per watershed per year and total number of tourist nights for the whole island per year

173 were available. This tourism index was created by dividing the number of hotels per watershed

174 by the total number of hotels for the whole island and multiplied by total number of tourist

175 nights. The resulting index gave an approximate number of tourist nights per watershed per year.

176 A more extensive spatial analysis was done on the rainfall data using ArcView GIS. Simulated

177 monthly rainfall totals generated by Staub et al. 2014 were averaged across months and then by

178 watershed for each study year. In their study, monthly rainfall totals (2000-2011) from 85

179 stations, a digital elevation model (DEM) and location-specific landscape characteristics were

180 used to calculate linear relationships between mean rainfall and landscape characteristics on

181 Mauritius. The time and space-varying nature of the modeled relationships were then explored

182 by estimating separate models for each month (Staub, Stevens \& Waylen, 2014). Finally,

183 monthly rainfall totals for 1998 to 2011 were generated by removing the variability characteristic

184 to each month from the observed data, interpolating these values across space using ordinary

185 kriging, and adding these back to the spatial mean model for the corresponding month (Staub,

186 Stevens \& Waylen, 2014). Since rainfall was a proxy for runoff in this study the rainfall data

$187(\mathrm{~mm})$ per watershed per year was multiplied by their respective watershed areas $\left(\mathrm{m}^{2}\right)$ and divided

188 by 1000 to obtain a volume of rainfall per watershed $\left(\mathrm{m}^{3}\right)$ per year.

189 (c) Linking the stressor effects arising within watersheds to study sites

190 Landscape characteristics including mountains and riverbeds were used to determine which

191 watershed(s) drained into which lagoons. This was done as multiple back-reef sites were found

192 in different lagoons and were thus impacted by different levels of land-based stressors. Study

193 sites and their respective watersheds were color-coded and are displayed in Fig. 1b. When sites 
194 from different lagoons shared a common watershed, one of the sites was colored white and the

195 watersheds to which it was linked were shaded (Fig. 1b). The fore-reefs sites were linked to the

196 same watersheds as their complementary back-reef sites. Table S2 in Supplemental Materials

197 provides the long-term mean of each of the four local stressors by site for the period spanning 1981998 to 2010.

199

200 Statistical analysis

201 All statistical tests in this study were done using R (R Core Team, 2015).

202

(a) Trends in benthic cover for 1998 - 2010

203 Temporal changes in benthic cover on the back- and fore-reefs were examined. A stacked bar 204 graph was made for 1999 to show how the benthic cover varies by site. The benthic groups were 205 aggregated into eight groups as it was difficult to visualize 23 groups ( 23 colors). The eight 206 groups were: Acropora corals, non-Acropora corals, macroalgae, turf algae, coralline algae, dead 207 corals, other living organisms and non-living organisms (included rubbles).

208 A mean percent cover per year for each benthic group was calculated for each season and for 209 each study site. This was done by averaging data from the three transects. These mean values 210 were then used in Spearman's rank correlation tests to determine whether there were any 211 correlations between the benthic group cover and year. Only sites that had at least five or more 212 years of observation were considered for this study. Year 2001 was also not considered as only 213 four back- and two fore-reefs sites were surveyed, and therefore the data for this year were not 214 representative of the whole island. 
215 Temporal changes in total stony coral percent cover were also studied. A long-term mean for

216 each site was calculated by averaging the annual percent cover of total live stony coral for the

217 13-year period for each site. This long-term mean for each site was subtracted from their

218 respective annual means and the resulting values were used to create anomaly plots. These plots

219 showed the mean annual deviations in total live stony coral cover for the 1998 to 2010 period.

220 Two sets of anomaly plots were created, one from summer data and one from winter data.

\section{1 (b) Land-based stressors - relationship with benthic cover trends}

222 Temporal trends in land-based stressors were first examined by plotting total human population,

223 total land area under agriculture, total number of tourists and total rainfall per year for the whole

224 island against time. A Z-score was used on the y-axis to facilitate comparisons between stressors,

225 which had widely different ranges.

226 To investigate the effects of the land-based stressors on the benthic communities, we used a

227 combination of non-Metric Multidimensional Scaling analyses (nMDS) on Bray-Curtis distances

228 (Borcard, Gillet \& Legendre, 2011) and the 'envfit' function of the package vegan in R (Oksanen

229 et al., 2015). The mean percent cover per benthic group per year were first calculated using data

230 from both summer and winter; the seasonal data were combined since we only had one set of

231 annual data for the land-based stressors (no seasonal data) to which the benthic data were tested

232 with. The mean percent cover values were then used in nMDS to generate ordination plots for

233 each site. The ordination plots indicate the scale of changes in community structure at each site.

234 Then, using the 'envfit' function, data from the four stressors were fitted onto these ordinations

235 to determine which ones had a significant correlation with the placement of benthic community

236 observations in ordination space. The 'envfit' function considered the effects of each stressor

237 individually. 


\section{Results}

\section{1. Changes in benthic cover}

\section{0 (i) Individual sites}

241 Stony corals were the most abundant group at all sites. The back-reef sites had in general more

242 Acropora corals while the fore-reef sites had more of the non-Acropora corals (Fig. 2). All sites

243 had rubble and/or rocks (non-living category). The fore-reefs had in general more rocks. Turf

244 algae and macroalgae were present at most sites albeit in varying amounts. Coralline algae were

245 rarely detected. All sites had some dead corals; back-reef sites tended to have more dead corals

246 than the fore-reef sites. Very little of other living organisms were recorded at the study sites.

247 Changes in benthic cover varied a lot among sites (Table 1). The ' $\mathrm{X}$ ' was used to indicate

248 benthic groups not observed during the survey. The Acropora coral groups experienced a

249 decrease in cover over time. Although some non-Acropora coral groups also showed a

250 significant decreased, a few groups increased in abundance. In particular, non-Acropora

251 encrusting increased in cover at four back-reefs sites. Non-Acropora foliaceous, massive and

252 submassive also increased at one site each.

253 Other benthic groups studied showed variable responses (Table 1). The cover of dead corals

254 increased at four sites and decreased at one site. The cover of rubble increased at one site and

255 decreased at three sites. Turf algae cover increased at one and three sites. The cover of

256 macroalgae increased at three sites and decreased at two sites. Coralline algae increased at two

257 sites and soft corals at one site. Sand increased at two sites and decreased at three sites.

258 Millepora and sponges respectively decreased at one site and increased at one site. The group

259 'other live' decreased at two sites. No clear seasonal signal was detected except for turf algae

260 and macroalgae, which appeared to be more abundant in summer than in winter. 


\section{1 (ii) Anomaly plots - stony corals}

262 The summer anomaly plots showed that a large number of sites had a mean annual cover above

263 their respective long-term mean (more circles with warm colors) till 2005, after which this trend

264 was reversed; most sites afterwards had a mean annual cover below their respective long-term

265 mean (more circles with cold colors; Fig. 3). Not a single site in 2009 and 2010 had a mean

266 annual cover above their respective long-term mean. A similar trend was observed from the

267 winter anomaly plots, although not as clear as those from the summer data (Fig. 4).

\section{2. Island-wide trends for land-based stressors}

269 When local stressor trends for the whole island were examined, there were clear increases in

270 human population and the tourism index over the study time (Fig. 5). There was a general

271 decline in land area under agriculture from 2001 and 2008, after which more land were

272 cultivated. The big dip in cultivated land area in 1999 coincided with the big dip in annual

273 rainfall, the year with the lowest rainfall during the study period. There was more rain after 1999,

274 but it fluctuated quite a big over time.

\section{3. Land-based stressors - relationship with benthic cover}

276 Significant effects of human population were detected at 11 of the 15 study sites (Table 2).

277 Tourism and agriculture had significant effects respectively at five and four study sites. No

278 significant effects of rainfall were detected at any of the study sites. There were insufficient data

279 to carry out this test at Belle Mare (BME). The ' $\mathrm{X}$ ' in the table indicates that there were either

280 only a few years or no tourism data in the watersheds linked to these study sites. Therefore, it

281 was not possible to test for the effects of tourism at these sites. 


\section{Discussion}

283 Some significant changes in benthic cover occurred around the island of Mauritius during the

284 period of 1998 to 2010 . Among the stony corals, Acropora coral groups appeared to have been

285 the most impacted, decreasing in abundance at many sites. While the non-Acropora coral groups

286 also decreased in abundance at many sites, some groups however experienced an increase over

287 time. The increase in abundance of dead corals and rubble at some sites also supported the

288 observations of stony coral decline during the study period. Additionally, the decline in stony

289 corals appeared to be more important in second half of the study period for all sites. There was

290 little change in cover for the other benthic groups, some of which were quite rare. Our study also

291 suggests that humans are an important factor contributing to the demise of coral reefs around the

292 island.

293 The decline of Acropora corals around the island was expected as Acropora corals have been

294 reported to be most sensitive to natural and anthropogenic stressors (Marshall \& Baird, 2000;

295 Loya et al., 2001; Rachello-Dolmen \& Cleary, 2007; Cleary et al., 2008; Côté \& Darling, 2010).

296 In contrast, the non-Acropora coral groups, particularly ones with encrusting morphologies,

297 appeared to be more successful competitors on the reefs. Their morphology could be a key aspect

298 allowing them to have a higher mass transfer rate for gases and nutrients (Patterson, 1992),

299 which in turn could lead to faster removal of harmful superoxides and toxic radicals produced

300 during stressful events (Lesser, 1997). A study done in Japan also reported the greater survival of

301 corals with massive and encrusting morphologies after a bleaching event (Loya et al., 2001).

302 This increase of encrusting corals coupled with the loss of branching, digitate and tabulate

303 Acropora corals also suggest that the coral reefs around Mauritius have flattened and 
304 experienced a decline in habitat complexity. Similar flattening of reefs has been observed in the 305 Caribbean (Alvarez-Filip et al., 2009).

306 Interestingly, all study sites appeared to have experienced a more significant decline in stony 307 coral cover during the second half of the study period, i.e. around 2005 and onwards. These 308 observations suggest that a global rather than a local factor was involved. The 50-km Degree 309 Heating Weeks (DHW) data from Coral Reef Watch NOAA website for 2005 showed that the 310 reefs around Mauritius experienced severe heat stress $\left(4^{\circ} \mathrm{C}\right.$-weeks and above) for three 311 consecutive summer months (ending 29 March, 30 April and 31 May; Table S3). Therefore, 312 temperature was a most likely stressor contributing to impact severely the corals during 2005 , 313 which led to subsequent declines in cover. This temperature stress from 2005 was so severe that 314 the corals had not recovered by 2010.

315 The cover of other benthic groups such as macroalgae and turf algae did not change much at 316 most of the study sites, but they did appear to grow more in summer. These observations suggest 317 that there was in general a good top-down control by herbivores at these study sites. Herbivore 318 biomass is known to play an important role in coral reef dynamics and in mediating reef regime319 shifts (Jouffray et al., 2014). As observed on the Great Barrier Reef (De'ath, Lough \& Fabricius, 320 2009), herbivorous fish on the reefs of Mauritius also face less significant fishing pressure as 321 artisanal fisheries target mainly piscivorous fishes.

322 Coralline algae is important for coral larval settlement (Harrington et al., 2004) and their cover 323 did not change much at most sites; they only increased at two sites. Millepora spp, sponges, soft 324 corals, zooanthids and other live group were either quite rare at most sites and/or did not appear 325 to experience much change during the study. The lumping of species into larger groups could, 
326 however, have obscured temporal trends for individual species. For these rare groups, more

327 targeted approaches are needed to study them.

328 Human population was the land-based stressor that appeared to impact the most sites around

329 Mauritius. High human densities have previously been reported to impact negatively coral reef

330 communities (Mora, 2008; Sandin et al., 2008; Smith et al., 2016; Crane et al., 2017). However,

331 as also argued, it is not the number of people, but rather their activities that affect the coral reefs

332 (Sanderson et al., 2002; Mora, 2008). Tourism was the second most common stressor to impact

333 the reefs. Therefore, it appeared that the activities of the growing local population and the

334 tourism industry have contributed the most to affect the coral reefs. The fore-reef sites located on

335 the west coast also appeared to be primarily impacted by human population. These observations

336 suggest that fore-reefs may not be far enough from land to be isolated from the impacts of the

337 local human population. However, we had data for only four fore-reefs sites all located on the

338 west coast of the island, and this small sample size may not be adequate to draw broad

339 conclusions.

340 Agriculture appeared to affect only four study sites, however total land area under agriculture

341 was used as a proxy for its effects and may not be representative of its negative impacts, e.g., the

342 excessive use fertilizers and their detrimental effects are well documented (Markey et al., 2007;

343 Brodie et al., 2012). Similarly, rainfall did not appear to affect the coral reefs; the negative

344 impacts of runoff bringing pollutants to lagoons are also well documented (Fabricius, 2005;

345 Brodie et al., 2012). Therefore, investigating the impacts of specific human activities would

346 provide greater insights on the root causes of reef degradation around Mauritius. 
347 The coral reefs as we know them are changing rapidly and will continue to degrade under the

348 pressure of multiple natural and anthropogenic stressors. How coral reefs are going to change

349 and how to protect them so they maintain important ecosystem functions for future generations

350 remain a challenge. Our results showed that Acropora corals have been declining and suggest

351 that corals reefs are flattening. Moreover, our results also suggest that human are a contributing

352 factor to coral reef degradation and loss. Therefore, reducing the impacts of human activities

353 remains very important. Other studies focusing on biological traits that convey resilience in the

354 face of multiple stressors are needed better understand how benthic communities are going to

355 change in the future.

\section{Acknowledgements}

357 We would like to thank the Albion Fisheries Research Centre, Ministry of Fisheries, Government

358 of Mauritius for providing us with the benthic community dataset without which this work would

359 not have been possible. Jennifer Elliott expresses her deepest gratitude to the members of her

360 advisory committee, Peter Edmunds, Tarik Gouhier, Brian Helmuth and Steve Vollmer for their

361 thoughtful inputs during the execution of this work. This is contribution number XXX from the

362 Marine Science Center at Northeastern University.

\section{References}

364

365

366

367

368

369

370

371

372

373

374
Alvarez-Filip L, Dulvy NK, Gill JA, Cote IM, Watkinson AR 2009. Flattening of Caribbean coral reefs: region-wide declines in architectural complexity. Proceedings of the Royal Society B: Biological Sciences 276:3019-3025. DOI: 10.1098/rspb.2009.0339.

Bellwood D, Hughes T, Folke C, Nyström M 2004. Confronting the coral reef crisis. Nature 429:827-833.

Borcard D, Gillet F, Legendre P 2011. Numerical Ecology with R. New York, NY: Springer Science \& Business Media. DOI: 10.1007/978-1-4419-7976-6.

Brodie JE, Kroon FJ, Schaffelke B, Wolanski EC, Lewis SE, Devlin MJ, Bohnet IC, Bainbridge ZT, Waterhouse J, Davis AM 2012. Terrestrial pollutant runoff to the Great Barrier Reef: An update of issues, priorities and management responses. Marine Pollution Bulletin 65:81-100. DOI: 10.1016/j.marpolbul.2011.12.012. 
375

376

377

378

379

380

381

382

383

384

385

386

387

388

389

390

391

392

393

394

395

396

397

398

399

400

401

402

403

404

405

406

407

408

409

410

411

412

413

414

415

416

417

418

419

420

Bruno J, Selig E 2007. Regional decline of coral cover in the Indo-Pacific: timing, extent, and subregional comparisons. PLOS ONE 2:e711.

Burke LM, Reytar K, Spalding M, Perry A 2012. Reefs at risk revisited in the Coral Triangle. World Resource Institute, Washington DC.

Cleary DFR, De Vantier L, Giyanto, Vail L, Manto P, de Voogd NJ, Rachello-Dolmen PG, Tuti Y, Budiyanto A, Wolstenholme J, Hoeksema BW, Suharsono 2008. Relating variation in species composition to environmental variables: a multi-taxon study in an Indonesian coral reef complex. Aquatic Sciences 70:419-431. DOI: 10.1007/s00027-008-8077-2.

Coelho VR, Fenner D, Caruso C, Bayles BR, Huang Y, Birkeland C 2017. Shading as a mitigation tool for coral bleaching in three common Indo-Pacific species. Journal of Experimental Marine Biology and Ecology 497:152-163. DOI:

10.1016/j.jembe.2017.09.016.

Côté I, Darling E 2010. Rethinking Ecosystem Resilience in the Face of Climate Change. PLoS Biology 8:765-781.

Crane NL, Nelson P, Abelson A, Precoda K, Rulmal J, Bernardi G, Paddack M 2017. Atoll-scale patterns in coral reef community structure: Human signatures on Ulithi Atoll, Micronesia. PLOS ONE 12:e177083-19. DOI: 10.1371/journal.pone.0177083.

Darling ES, Alvarez-Filip L, Oliver TA, McClanahan TR, Côté IM 2012. Evaluating life-history strategies of reef corals from species traits. Ecology Letters 15:1378-1386. DOI: 10.1111/j.1461-0248.2012.01861.x.

De'ath G, Lough J, Fabricius K 2009. Declining coral calcification on the Great Barrier Reef. Science 323:116.

Edmunds PJ, Gates RD 2008. Acclimatization in tropical reef corals. Marine Ecology Progress Series 361:307-310. DOI: 10.3354/meps07556.

Fabricius KE 2005. Effects of terrestrial runoff on the ecology of corals and coral reefs: review and synthesis. 50:125-146. DOI: 10.1016/j.marpolbul.2004.11.028.

Gardner TA, Côté IM, Gill JA, Grant A, Watkinson AR 2003. Long-Term Region-Wide Declines in Caribbean Corals. Science 301:958-960. DOI: 10.1126/science.1086050.

Glynn PW, D'Croz L 1990. Experimental evidence for high temperature stress as the cause of El Nino-coincident coral mortality. Coral Reefs 8:181-191. DOI: 10.1086/511756?ref=searchgateway:e1b1fe 7c141c6f73655a09e8dffc067c.

Graham N, Wilson S, Jennings S, Polunin N, Bijoux J, Robinson J 2006. Dynamic fragility of oceanic coral reef ecosystems. Proceedings of the National Academy of Sciences 103:8425.

Harrington L, Fabricius K, De'ath G, Negri A 2004. Recognition and selection of settlement substrata determine post-settlement survival in corals. Ecology 85:3428-3437. DOI: 10.1890/04-0298.

Heron SF, Maynard JA, van Hooidonk R, Eakin CM 2016. Warming Trends and Bleaching Stress of the World's Coral Reefs 1985-2012. Scientific Reports 6:1-14. DOI: $10.1038 / \mathrm{srep} 38402$.

Hoegh-Guldberg O 1999. Climate change, coral bleaching and the future of the world's coral reefs. Marine and freshwater research:839-866.

Hughes TP, Anderson KD, Connolly SR, Heron SF, Kerry JT, Lough JM, Baird AH, Baum JK, Berumen ML, Bridge TC, Claar DC, Eakin CM, Gilmour JP, Graham NAJ, Harrison H, Hobbs J-PA, Hoey AS, Hoogenboom M, Lowe RJ, McCulloch MT, Pandolfi JM, Pratchett M, Schoepf V, Torda G, Wilson SK 2018. Spatial and temporal patterns of mass bleaching of corals in the Anthropocene. Science 359:80-83. DOI: 10.1126/science.aan8048. 
421 Hughes TP, Kerry JT, Álvarez-Noriega M, Álvarez-Romero JG, Anderson KD, Baird AH,

422

423

424

425

426

427

428

429

430

431

432

433

434

435

436

437

438

439

440

441

442

443

444

445

446

447

448

449

450

451

452

453

454

455

456

457

458

459

460

461

462

463

464

465

466 Babcock RC, Beger M, Bellwood DR, Berkelmans R, Bridge TC, Butler IR, Byrne M, Cantin NE, Comeau S, Connolly SR, Cumming GS, Dalton SJ, Diaz-Pulido G, Eakin CM, Figueira WF, Gilmour JP, Harrison HB, Heron SF, Hoey AS, Hobbs J-PA, Hoogenboom MO, Kennedy EV, Kuo C-Y, Lough JM, Lowe RJ, Liu G, McCulloch MT, Malcolm HA, McWilliam MJ, Pandolfi JM, Pears RJ, Pratchett MS, Schoepf V, Simpson T, Skirving WJ, Sommer B, Torda G, Wachenfeld DR, Willis BL, Wilson SK 2017. Global warming and recurrent mass bleaching of corals. Nature 543:373-377. DOI: 10.1038/nature21707.

IPCC 2014. Climate change 2014: synthesis report. contribution of working groups I, II and III to the fifth assessment report of the Intergovernmental Panel on Climate Change . IPCC, Geneva, Switzerland.

Jackson J, Kirby M, Berger W, Bjorndal K, Botsford L, Bourque B, Bradbury R, Cooke R, Erlandson J, Estes J 2001. Historical overfishing and the recent collapse of coastal ecosystems. Science 293:629-637.

Jokiel PL, Brown EK 2004. Global warming, regional trends and inshore environmental conditions influence coral bleaching in Hawaii. Global Change Biology 10:1627-1641. DOI: 10.1111/j.1365-2486.2004.00836.x.

Jouffray JB, Nyström M, Norstrom AV, Williams ID, Wedding LM, Kittinger JN, Williams GJ 2014. Identifying multiple coral reef regimes and their drivers across the Hawaiian archipelago. Philosophical Transactions of the Royal Society of London. Series B: Biological Sciences 370:20130268-20130268. DOI: 10.1098/rstb.2013.0268.

Kaiser L 1983. Unbiased estimation in line-intercept sampling. Biometrics 39:965-976. DOI: $10.2307 / 2531331$.

Lesser MP 1997. Oxidative stress causes coral bleaching during exposure to elevated temperatures. Coral Reefs 16:187-192. DOI: 10.1007/s003380050073.

Loya Y, Sakai K, Yamazato K, Nakano Y, Sambali H, Van Woesik R 2001. Coral bleaching: the winners and the losers. Ecology Letters 4:122-131. DOI: 10.1046/j.14610248.2001.00203.x.

Markey KL, Baird AH, Humphrey C, Negri AP 2007. Insecticides and a fungicide affect multiple coral life stages. Marine Ecology 330:127-137. DOI: 10.3354/meps330127.

Marshall PA, Baird AH 2000. Bleaching of corals on the Great Barrier Reef: differential susceptibilities among taxa. Coral Reefs 19:155-163. DOI: 10.1007/s003380000086.

Moothien Pillay R, Terashima H, Kawasaki H 2002. The extent and intensity of the 1998 mass bleaching event on the reefs of Mauritius, Indian Ocean. 4:43-52.

Moothien Pillay R, Terashima H, Venkatasami A, Uchida H 2002. Field guide to corals of Mauritius. Albion Fisheries Research Center, Ministry of Fisheries, Mauritius.

Mora C 2008. A clear human footprint in the coral reefs of the Caribbean. Proceedings of the Royal Society B: Biological Sciences 275:767.

Nakamura T, Van Woesik R 2001. Water-flow rates and passive diffusion partially explain differential survival of corals during the 1998 bleaching event. Marine Ecology Progress Series 212:301-304.

Nakamura T, Van Woesik R 2005. Photoinhibition of photosynthesis is reduced by water flow in the reef-building coral Acropora digitifera. Marine Ecology Progress Series 301:109-118.

Oksanen J, Blanchet FG, Kindt R, Legendre P, Minchin PR, OHara RB, Simpson GL, Solymos P, Stevens MH, Szoecs E, Wagner H 2015. Vegan: Community Ecology Package. R package version 2.3-2. http://CRAN.R-project.org/package=vegan.

Peer] reviewing PDF | (2018:02:25851:1:1:NEW 4 Oct 2018) 
467 Pandolfi JM, Bradbury RH, Sala E, Hughes TP, Bjorndal KA, Cooke RG, McArdle D, Mcclenachan L, Newman MJH, Paredes G, Warner RR, Jackson JBC 2003. Global trajectories of the long-term decline of coral reef ecosystems. Science 301:955-958. DOI: $10.1126 /$ science. 1085706 .

Patterson MR 1992. A mass transfer explanation of metabolic scaling relations in some aquatic invertebrates and algae. Science 255:1421-1423.

Proag V 1995. The geology and water resources of Mauritius. Mahatma Gandhi Institute Press, Mauritius.

R Core Team 2015. R: A language and environment for statistical computing. R Foundation for Statistical Computing, Vienna, Austria. https://www.r-project.org/.

Rachello-Dolmen PG, Cleary DFR 2007. Relating coral species traits to environmental conditions in the Jakarta Bay/Pulau Seribu reef system, Indonesia. Estuarine Coastal and Shelf Science 73:816-826. DOI: 10.1016/j.ecss.2007.03.017.

Roberts CM, McClean CJ, Veron JEN, Hawkins JP, Allen GR, McAllister DE, Mittermeier CG, Schueler FW, Spalding M, Wells F, Vynne C, Werner TB 2002. Marine biodiversity hotspots and conservation priorities for tropical reefs. Science 295:1280-1284. DOI: 10.1126/science. 1067728 .

Sanderson EW, Jaiteh M, Levy MA, Redford KH, Wannebo AV, Woolmer G 2002. The human footprint and the last of the wild. Science 25:891-904.

Sandin SA, Smith JE, DeMartini EE, Dinsdale EA, Donner SD, Friedlander AM, Konotchick T, Malay M, Maragos JE, Obura D, Pantos O, Paulay G, Richie M, Rohwer F, Schroeder RE, Walsh S, Jackson JBC, Knowlton N, Sala E 2008. Baselines and degradation of coral reefs in the Northern Line Islands. PLoS ONE 3:e1548. DOI: 10.1371/journal.pone.0001548.

Smith JE, Brainard R, Carter A, Grillo S, Edwards C, Harris J, Lewis L, Obura D, Rohwer F, Sala E, Vroom PS, Sandin S 2016. Re-evaluating the health of coral reef communities: baselines and evidence for human impacts across the central Pacific. Proceedings of the Royal Society B: Biological Sciences 283:20151985-9. DOI: 10.1098/rspb.2015.1985.

Smith SV, Kimmerer WJ, Laws EA, Brock RE, Walsh TW 1981. Kaneohe Bay sewage diversion experiment: perspectives on ecosystem responses to nutritional perturbation. Pacific Science 35:279-395.

Staub CG, Stevens FR, Waylen PR 2014. The geography of rainfall in Mauritius: Modelling the relationship between annual and monthly rainfall and landscape characteristics on a small volcanic island. Applied Geography 54:222-234. DOI: 10.1016/j.apgeog.2014.08.008. Turner J, Klaus R 2005. Coral reefs of the Mascarenes, Western Indian Ocean. Philosophical Transactions of the Royal Society A: Mathematical, Physical and Engineering Sciences 363:229-250.

505 Figure 1. Mauritius. (a) The island of Mauritius in the southwestern Indian Ocean. (b) Map of

506 the island showing back- (circles) and fore- (stars) reef sites. Land area is divided into several

507 watersheds (catchment areas). Study sites were connected to adjacent watersheds(s) and are 
508 color-coded identically. The back-reef site colored white is connected to adjacent shaded

509 watersheds.

510 Figure 2. Benthic cover by site for 1999 . The benthic cover data (23 categories) were aggregated

511 into eight groups to facilitate visualization of the data.

512 Figure 3. Anomaly plots for stony coral cover- Summer data. a) Long-term means for each site

513 for the period of 1998 - 2010; year 2001 was not included as very few sites were surveyed

514 during that year. (b-m) Data for each year excluding 2001. Warm colors indicate cover was

515 above long-term mean and cold colors indicate that cover was below long-term mean.

516 Figure 4. Anomaly plots for stony coral cover - Winter data. a) Long-term means for each site

517 for the period of $1998-2010$; year 2001 was not included as very few sites were surveyed

518 during that year. (b-m) Data for each year excluding 2001. Warm colors indicate cover was

519 above long-term mean and cold colors indicate that cover was below long-term mean.

520 Figure 5. Trends in land-based stressors for 1998 - 2010. The total human population (total

521 number of local people), total number of tourists, total surface area under agriculture and the

522 total rainfall for each year are shown.

523 Table 1. Temporal trends in benthic cover at individual sites. Spearman rank correlation results.

524 Only significant results are shown $(\mathrm{p}<0.05)$. The ' $\mathrm{X}$ ' indicates that benthic group was not

525 observed. Only sites that had at least five years of observation were used in this test. See M\&M

526 for full site names.

527 Table 2. Land-based stressors and their relationship with benthic cover. 


\section{Supplementary materials}

530 Table S1. Number of study years available by site. See M\&M for site names.

531

532 Table S2. Long-term mean of local stressor by site for 1998-2010. Numbers in brackets indicate

533 rank of each station. Rank goes from least to most abundant. See M\&M for full site names.

534 Table S3. Degree Heating Weeks data from NOAA. The seawater around Mauritius experienced

535 severe temperature stress during the months of March to April 2005. 


\section{Figure 1}

Mauritius

(a) The island of Mauritius in the southwestern Indian Ocean. (b) Map of the island showing back- (circles) and fore- (stars) reef sites. Land area is divided into several watersheds (catchment areas). Study sites were connected to adjacent watersheds(s) and are colorcoded identically. The back-reef site colored white is connected to adjacent shaded watersheds. 


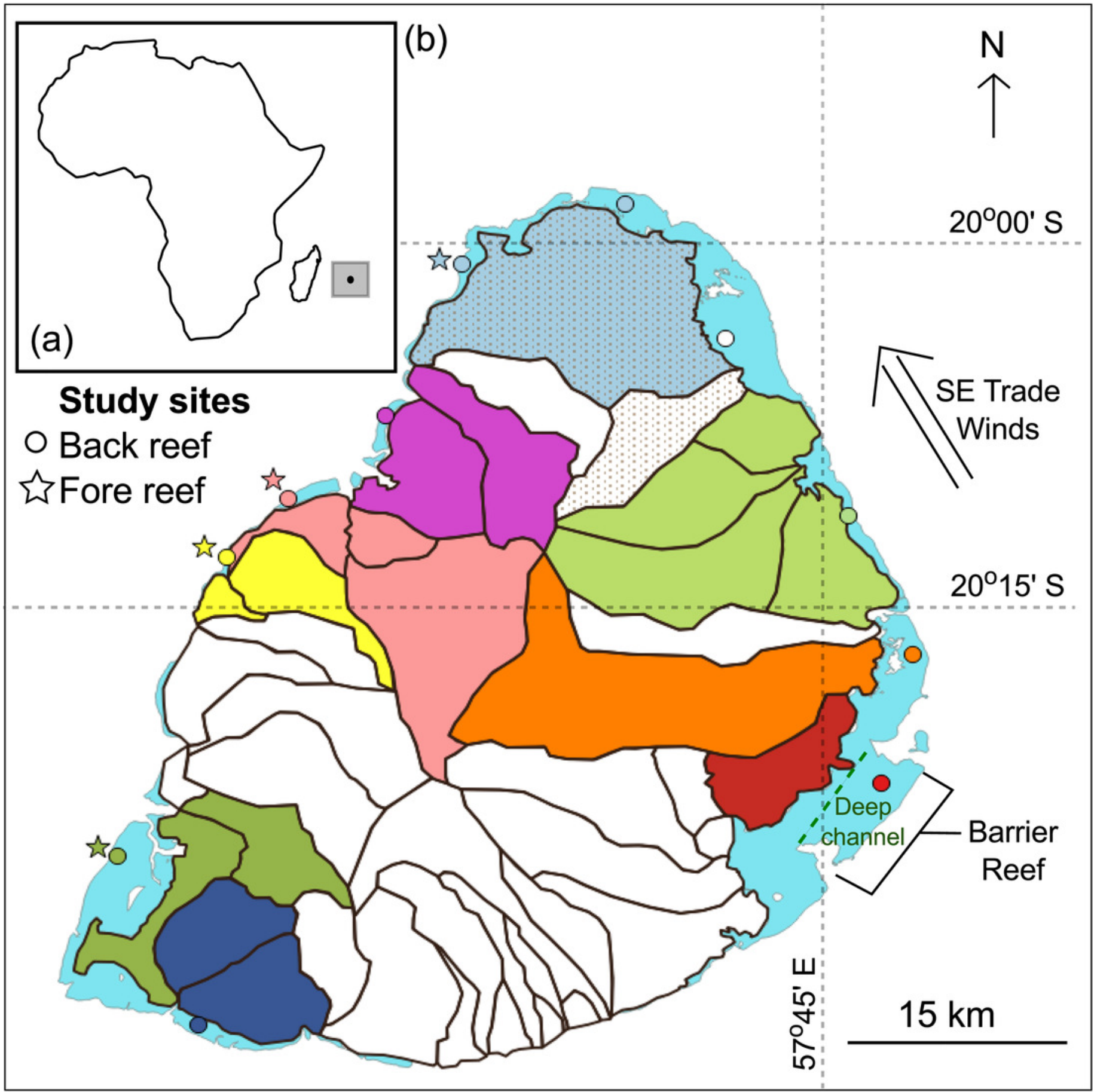


Figure 2 (on next page)

Benthic cover by site for 1999

The benthic cover data ( 23 categories) were aggregated into eight groups to facilitate visualization of the data. 


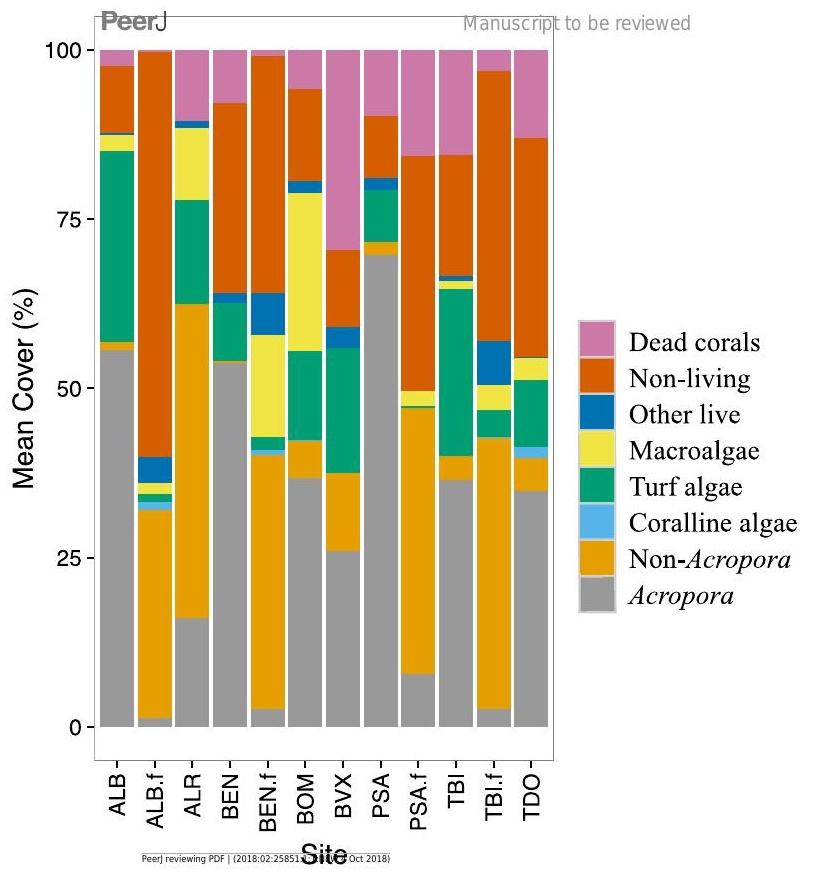




\section{Figure 3}

Anomaly plots for stony coral cover- Summer data

(a) Long-term means for each site for the period of 1998 - 2010; year 2001 was not included as very few sites were surveyed during that year. (b-m) Data for each year excluding 2001. Warm colors indicate cover was above long-term mean and cold colors indicate that cover was below long-term mean. 

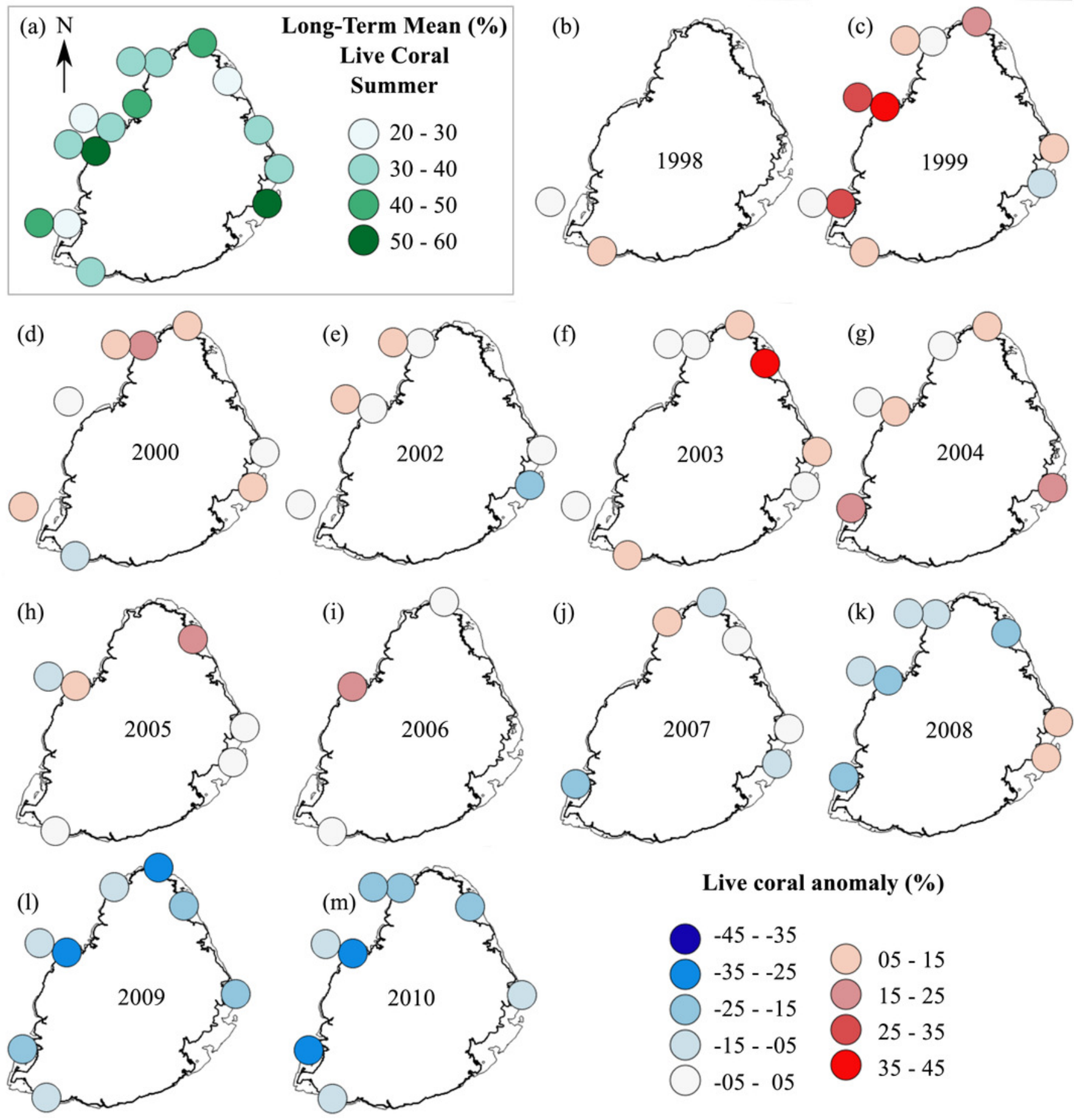

Live coral anomaly $(\%)$
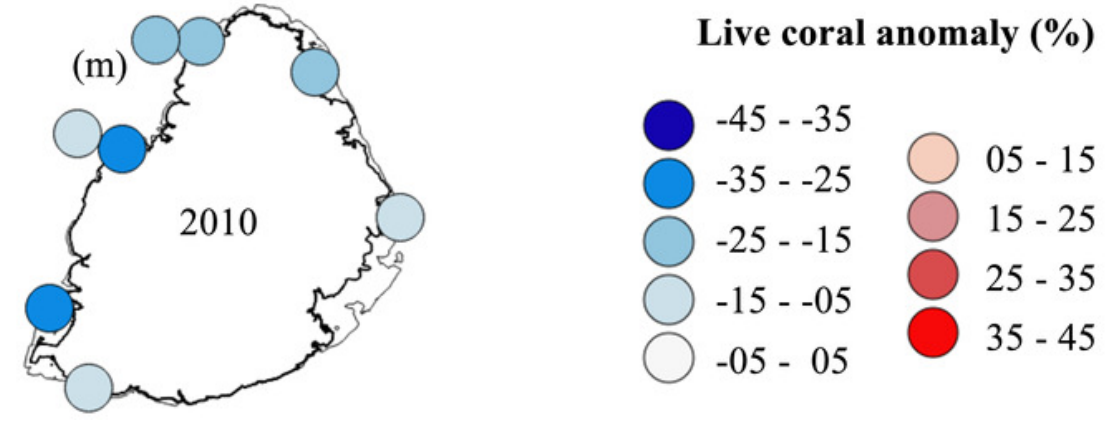


\section{Figure 4}

Anomaly plots for stony coral cover - Winter data

a) Long-term means for each site for the period of 1998 - 2010; year 2001 was not included as very few sites were surveyed during that year. (b-m) Data for each year excluding 2001. Warm colors indicate cover was above long-term mean and cold colors indicate that cover was below long-term mean. 

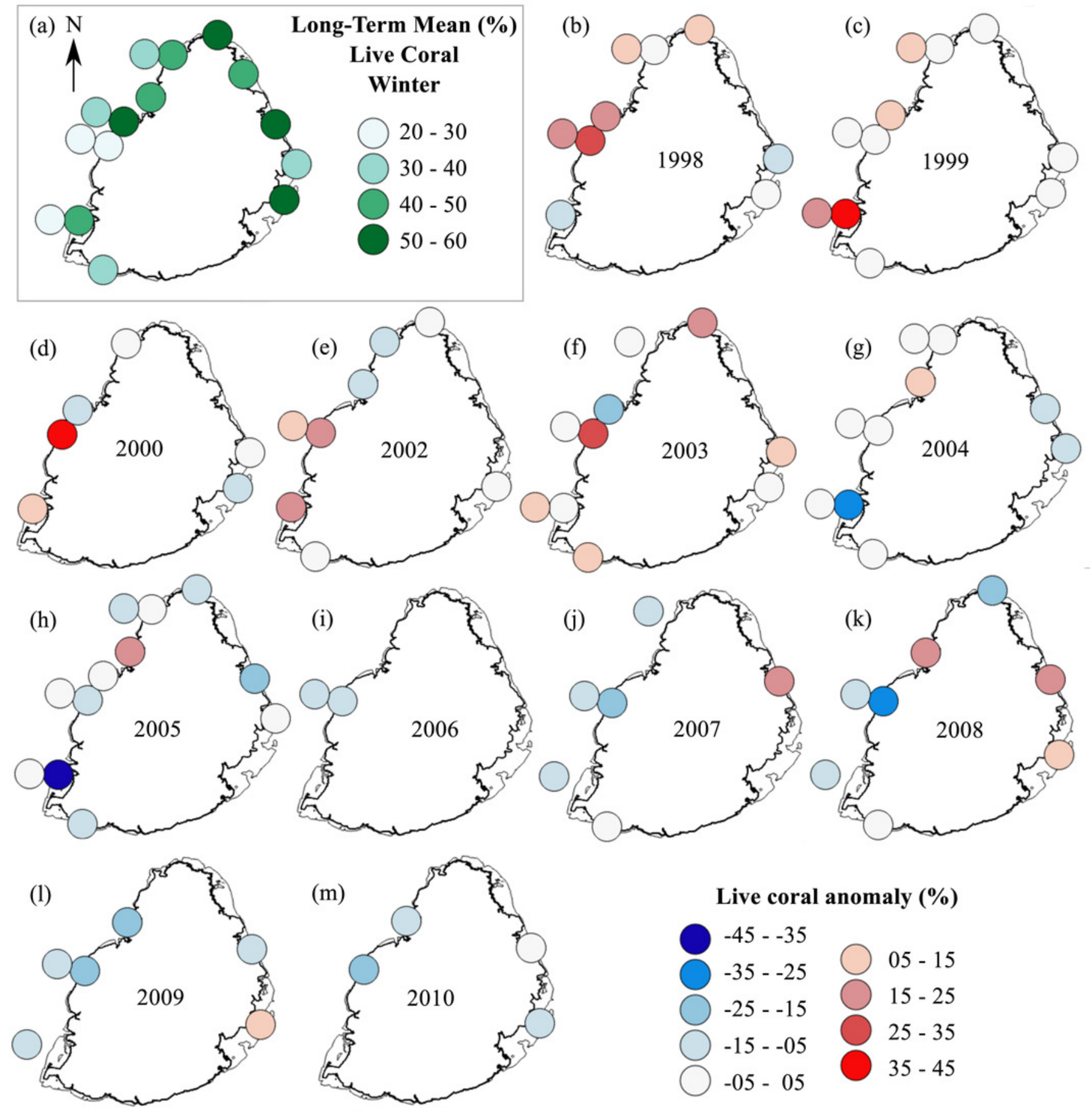
Figure $\mathbf{5}$ (on next page)

Trends in land-based stressors for 1998 - 2010

The total human population (total number of local people), total number of tourists, total surface area under agriculture and the total rainfall for each year are shown. 


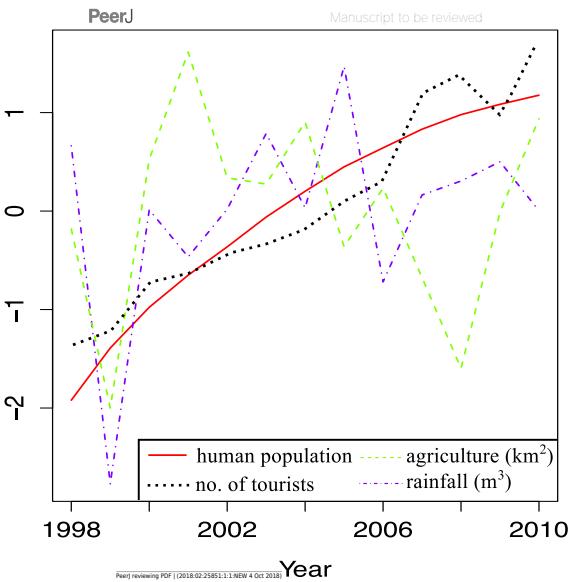




\section{Table $\mathbf{1}$ (on next page)}

Temporal trends in benthic cover at individual sites

Spearman rank correlation results. Only significant results are shown $(p<0.05)$. The ' $X$ ' indicates that benthic group was not observed. Only sites that had at least five years of observation were used in this test. See M\&M for full site names. 
1 Table 1. Temporal trends in benthic cover at individual sites. Spearman rank correlation results. Only significant results are shown (p $2<0.05)$. The ' $X$ ' indicates that benthic group was not observed. Only sites that had at least five years of observation were used in this 3 test. See M\&M for full site names.

\begin{tabular}{|c|c|c|c|c|c|c|c|c|c|c|c|c|c|c|}
\hline 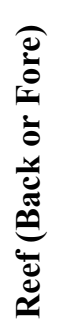 & 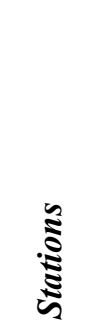 & $\begin{array}{l}5 \\
5 \\
5 \\
5 \\
5 \\
5 \\
5 \\
5\end{array}$ & $=$ & 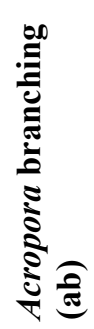 & 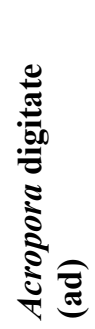 & 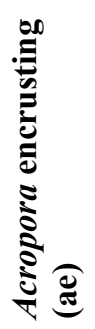 & 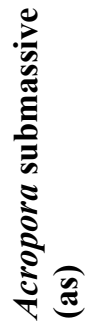 & 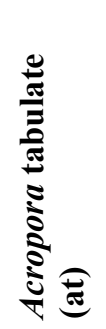 & 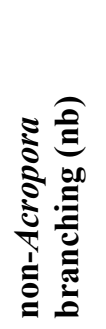 & 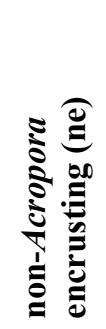 & 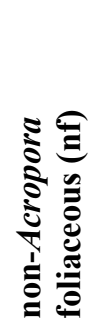 & 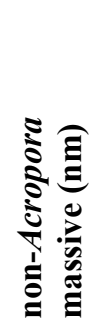 & 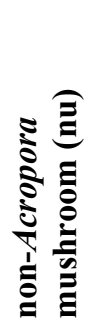 & 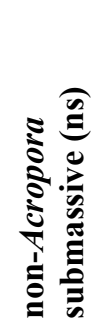 \\
\hline B & ALB & $\mathrm{W}$ & 12 & -0.87 & $X$ & $X$ & $X$ & & & & -0.58 & & & -0.80 \\
\hline B & ALR & $\mathrm{S}$ & 7 & & $X$ & & $X$ & $X$ & & & -0.96 & & & \\
\hline B & ALR & W & 6 & & $X$ & & $X$ & $X$ & & & & & & \\
\hline B & BDT & W & 6 & & X & $X$ & $X$ & & $X$ & +0.87 & & & & \\
\hline B & BEN & $\mathrm{S}$ & 8 & & -0.76 & $X$ & $X$ & -0.91 & & & X & & & \\
\hline B & BEN & W & 7 & & & $X$ & $X$ & & -0.80 & & X & & & \\
\hline B & BME & W & 6 & & $X$ & $X$ & $X$ & & & & $X$ & $X$ & $X$ & $X$ \\
\hline B & ВОМ & $\mathrm{S}$ & 8 & -0.71 & $X$ & $X$ & $X$ & & & & & $X$ & & \\
\hline B & BOM & W & 7 & & $X$ & $X$ & $X$ & & & & & $X$ & & \\
\hline B & BVX & $\mathrm{S}$ & 8 & & & $X$ & & & & +0.87 & +0.70 & & & \\
\hline B & BVX & W & 8 & -0.88 & & $X$ & & -0.73 & -0.85 & & +0.95 & & & \\
\hline B & PDO & $\mathrm{S}$ & 6 & X & $X$ & $X$ & $X$ & & X & & -0.93 & -0.84 & & -0.82 \\
\hline B & PSA & $\mathrm{S}$ & 8 & -0.78 & $X$ & $X$ & & $X$ & & $X$ & X & & & \\
\hline B & PSA & W & 5 & & $X$ & $X$ & & $\mathrm{X}$ & & $\mathrm{X}$ & $X$ & & & \\
\hline B & TBI & $\mathrm{S}$ & 9 & & & $X$ & $X$ & -0.78 & $X$ & +0.78 & & & & \\
\hline B & TBI & W & 5 & & & $X$ & $X$ & & X & & & & & -0.86 \\
\hline B & TDO & $\mathrm{S}$ & 9 & & & $X$ & $X$ & -0.73 & -0.73 & +0.83 & & +0.67 & & +0.82 \\
\hline B & TDO & W & 6 & & & $X$ & $\mathrm{X}$ & & & & & & & \\
\hline $\mathbf{F}$ & ALB & W & 10 & & & & & $X$ & & -0.76 & & & $X$ & \\
\hline $\mathbf{F}$ & BEN & $\mathrm{S}$ & 5 & & & & & $X$ & & & & & $X$ & \\
\hline $\mathbf{F}$ & BEN & W & 7 & & -0.97 & & & $X$ & -0.80 & & & -0.82 & $X$ & \\
\hline $\mathbf{F}$ & PSA & $\mathrm{S}$ & 8 & & & & -0.76 & $X$ & & & & & & -0.80 \\
\hline $\mathbf{F}$ & TBI & $\mathrm{S}$ & 6 & -0.84 & & $X$ & & & -0.84 & & & & $X$ & -0.86 \\
\hline $\mathbf{F}$ & TBI & W & 6 & & & $X$ & & & & & & & $X$ & \\
\hline
\end{tabular}


7 Table 1 continued

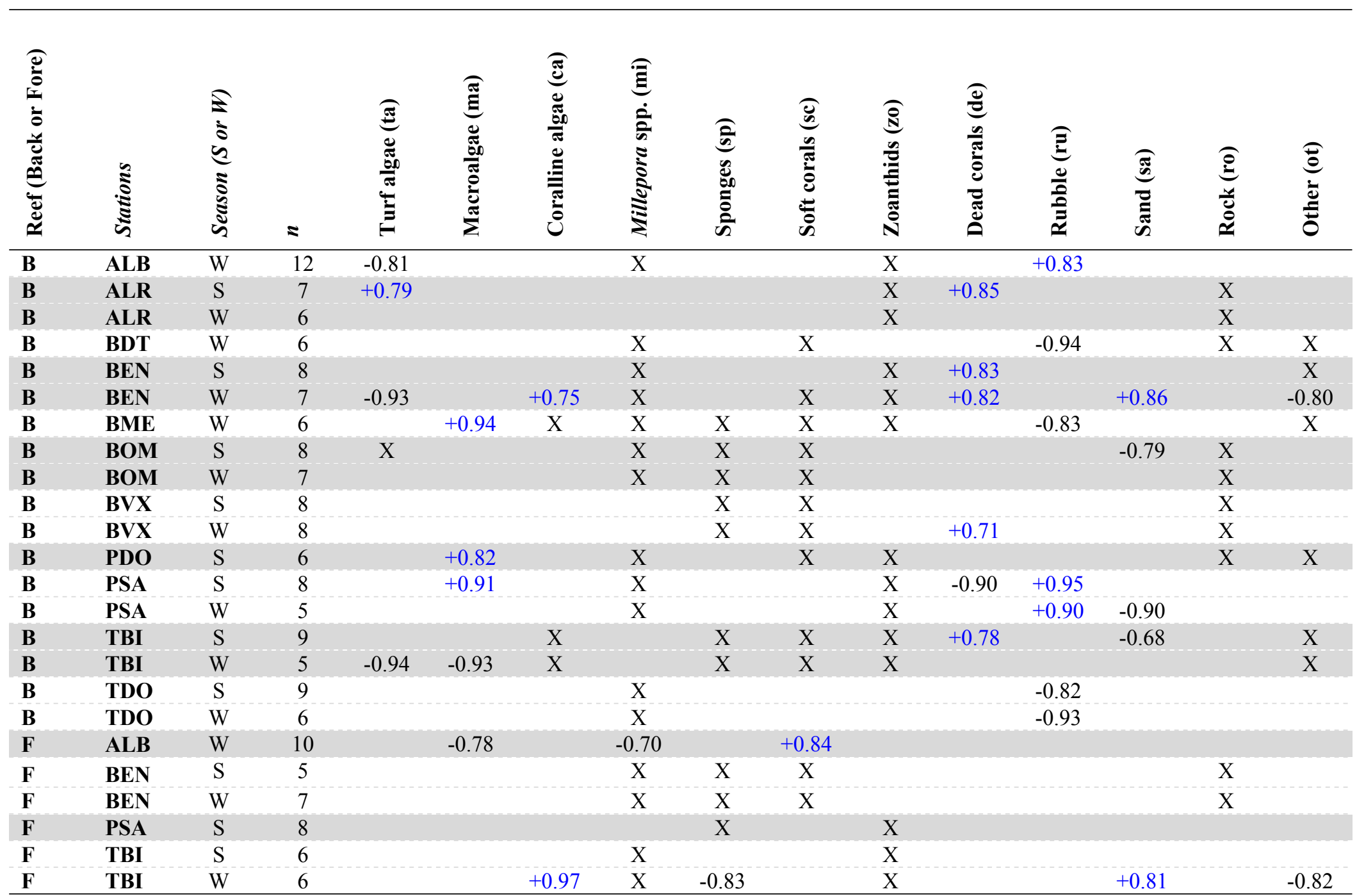

8 


\section{Table 2 (on next page)}

Land-based stressors and their relationship with benthic cover.

nMDS results. 
1 Table 2. Land-based stressors and their relationship with benthic cover.

\begin{tabular}{|c|c|c|c|c|c|c|c|}
\hline Station & $\mathbf{N}$ & Reef & 2-D Stress & Population & Tourism & Agriculture & Rainfall \\
\hline ALB & 12 & Back & 0.03 & $*$ & $\mathrm{X}$ & $*$ & \\
\hline ALR & 11 & Back & 0.09 & $*$ & $*$ & & \\
\hline BDT & 8 & Back & 0.06 & & & & \\
\hline BEN & 11 & Back & 0.06 & $*$ & $*$ & $*$ & \\
\hline $\mathrm{BME}$ & 7 & Back & Insufficient data & & & & \\
\hline BOM & 12 & Back & 0.20 & & $\mathrm{X}$ & & \\
\hline BVX & 11 & Back & 0.09 & $*$ & $X$ & & \\
\hline PDO & 8 & Back & 0.04 & $*$ & $*$ & $*$ & \\
\hline PSA & 11 & Back & 0.07 & $*$ & & $*$ & \\
\hline TBI & 11 & Back & 0.11 & $*$ & $*$ & & \\
\hline TDO & 11 & Back & 0.10 & $*$ & $\mathrm{X}$ & & \\
\hline ALB & 11 & Fore & 0.09 & $*$ & $\mathrm{X}$ & & \\
\hline BEN & 10 & Fore & 0.11 & & & & \\
\hline PSA & 10 & Fore & 0.10 & $*$ & & & \\
\hline TBI & 10 & Fore & 0.09 & $*$ & $*$ & & \\
\hline TOTAL & & & & 11 & 5 & 4 & 0 \\
\hline
\end{tabular}

2 